\title{
Foreword
}

\section{PROGRESS REPOR'I ON THE BURGEONING RELATIONS BETWEEN THF, JOURNAL AND BOSTON UNIVERSITY SCHOOL OF LAW}

On August 1, 1979, the American Society of Law \& Medicine executed an agreement with Boston University providing for the gradual sharing by the University and its law school faculty and students of the Society's role as publisher of the American Journal of Law i Medicine, and giving the University an option to purchase the Journal as of June 30, 1981.

With the execution of this agreement by Flliot Sagall and myself, the Society embarked on another of those unique ventures for which the Society is now famous: creation of a new type of law-school-based publication edited jointly by practitioners, academics, and students. If successful, we expect that this arrangement might become a model for specialty-publication developments on other subjects at other major law schools throughout the country.

This agrement represents a further development in the productive relations between the Society and Boston University School of I aw and its Dean, Richard Speidel. Under the agreement's terms, the Journal will retain its present subject matter and editorial policy, while benefiting from the additional scholarly resources made available by close association with Boston University School of Law.

The agreement specifies guidelines for a two-stage transition period that will extend for five years from the date of exccution. During the first phase of this period, through June 30, 1981, the Joumal's Board of Editors will continue to exercise its current supervisory functions. An Editorial Policy Committee, including myself as Fditor-in.Chief and Judith Lesser as Managing Editor, as well as representatives of Boston University School of Law and of the American Society of Iaw \& Medicine, will have dayto-day editorial control over the style and content of the Journal. During this first stage, the Society will retain its ownership and responsibility for production as at present.

By the close of the 1979.80 academic year, the involvement of Boston College Law School in the Journal will cease. At the same time, Boston University School of Law students will assume full editorial responsibility for student notes, as well as an important role in the evaluation and editing of professional articles. In carrying out these expanded functions, however, the student editors will continue to be subject to the overall supervision of 
the Board of Editors, of the Editorial Policy Committee, and of myself as Fditor-in.Chicf. Consequently, readers will find that the increased participation of Boston University law students in production of the Journal will permit us to maintain its present scope, format, and cditorial quality, while also permitting us to increase its size.

At the close of the first phase of the transitional period, July 31, 1981, I will retire from my position as Editor-in.Chicf, an office I am proud to say I have filled for all six years of the Journal's existence; howcver, I will con. tinue my association with the Journal in the capacity of Founding Editor. in-Chief Emeritus. Similarly, the existing Board of Editors and Editorial Policy Committee will remain in their positions after this date. My successor Editor.in.Chief will be chosen by the Editorial Policy Committee from the full-time faculty of Boston University School of Law. As a result, the Journal will continue over its lifetime to be a professionally edited medicolegal publication, rather than an entirely student-run law review.

If Boston University exercises its purchase option, it will succeed to full ownership and responsibility for production of the Journal as of Junc 30, 1981. Under the terms of the agreement, the University has committed itself for at least the balance of the five.ycar transition period to maintain the Journal's current name, format, and content, as well as to ensure that faculty members of the School of Law exercise editorial control over professional articles appearing in the Journal. Further continuity is assured by the retention of two seats on the Editorial Policy Committee by representatives of the American Society of Law \& Medicine. Finally, the agreement binds Boston University for the full five-year transition period to continue publication of the Journal essentially in its present form.

In summary, the agreement makes clear the commitment of Boston University to maintain the same subject matter, editorial policy, and professional quality that have characterized the Journal in the past. Moreover, the agreement builds on this foundation by securing for the Journal the academic resources offered by close association with a major law school, and for the Society's members a means of continuing to receive the benefits of the Joumal without additional charge, as a benefit of their membership dues. I am confident that the agreement will develop further the value and usefulness of the Journal to the medicolegal community, and I believe that Journal readers will share in this conclusion.

John A. Norris, J.D., M.B.A.

Editor-in.Chief 